\title{
Knowledge, Attitude, Perception of Biological Science and Healthcare Professional Students to Complementary and Alternative Medicine Health Belief and Practice in Southeastern Region of Bangladesh: A Comparative Study
}

\section{A. S. M. Ali Reza1, Nahid Sikdar ${ }^{1}$, Mst. Samima Nasrin ${ }^{1}$, Md Atiar Rahman², Abu Montakim Tareq ${ }^{1}$, A. H. M. Khurshid Alam ${ }^{3}$, Sanjida Sharmin' and Mohammed Abu Sayeed ${ }^{1}$}

\author{
${ }^{1}$ Department of Pharmacy, Faculty of Science and Engineering, International Islamic University \\ Chittagong, Chittagong-4318, Bangladesh \\ ${ }^{2}$ Department of Biochemistry and Molecular Biology, University of Chittagong, Chittagong-4331, Bangladesh \\ ${ }^{3}$ Department of Pharmacy, University of Rajshahi, Rajshahi-6205, Bangladesh
}

(Received: November 16, 2020; Accepted: July 4, 2021; Published (Web): July 15, 2021)

\begin{abstract}
The health professionals require scientific knowledge to advise their patients on complementary and alternative medicines (CAM). Previously, several studies were conducted regarding the CAM perception, attitude and use on health care professionals only; in contrast, our study encompasses both students of health care professionals and other disciplines. The aim of this study was to compare the attitudes and perception about CAM practices between students of biological sciences (Biochemistry and Molecular Biology, Microbiology and Botany) and health care professionals (Pharmacy and medical students) in public and private universities located in the southeastern region in Bangladesh. The questionnaire-based study conducted on 332 systematically sampled students (four private and one public universities) located in the southeastern region in Bangladesh. The cross-sectional study was conducted from March to July, 2018. All students showed a positive attitude towards CAM use. Herbal medicine, homeopathy, nutritional supplements followed by hypnosis, massage, spiritual healing, and meditation were the most commonly known and used CAM modalities. Most of the students (40.7\%) believed that the integration of CAM and conventional medicine should be essential in health care setting. The major obstacles for CAM use are patient interest $(48.2 \%)$ and lack of physician interest (43.4\%). In addition, 36.7\% students believed that CAM practices should be included in their school's curriculum. Moreover, 39.5\% students assumed that CAM knowledge is important to their daily life. Biological sciences and healthcare professional students of Bangladesh showed positive perception on CAM uses.
\end{abstract}

Key words: Complementary and alternative medicine (CAM), Awareness, Biological sciences and healthcare students.

\section{Introduction}

The National Center for Complementary and Integrative Health (NCCIH) declared CAM as a group of diverse medical and health care systems, practices, and products that are not presently considered to be a part of conventional medicine (Tabish, 2008). The acceptability of CAM increases in the commencement of the $19^{\text {th }}$ century and became widespread modalities for ameliorating diseases. In USA almost $67.0 \%$ of its population using at least one form of CAM in their daily life (Smith et al., 2007). CAM covers products obtained from nature (herbs and probiotics), mind, and body practices (acupuncture, chiropractic, massage therapy, hypnosis, spiritual healing, meditation, etc.) and other traditional medical practices such as African

Corresponding author: A. S. M. Ali Reza, E-mail:alirezaru@gmail.com

DOI: https://doi.org/10.3329/bpj.v24i2.54714 
traditional medicine, Chinese traditional medicine, and Indian Ayurvedic medicine (Babar et al., 2019; Bellah et al., 2017; Haque et al., 2020; Hossen et al., 2021; Rahman et al., 2021; Uddin et al., 2018).

In developing countries, CAM practice has long been used by local communities as a prime source of their healthcare system to improve a huge number of diseases (Ansari et al., 2017; Hossain et al., 2020; Moni et al., 2021; Rahman et al., 2021). The uses of CAM increased significantly both the developed and developing countries due to its accessibility, affordability, and good perception about safety comparing to conventional medicine. In Bangladesh, $70-75 \%$ populations are using traditional medicine in the form of herbal, homeopathy, religious, and magical methods (Saha et al., 2017). Considering the aforesaid evidences, the objectives of this study were to evaluate the awareness, attitude, and perception of CAM between biological sciences students (Biochemistry and Molecular Biology, Microbiology, and Botany) and future healthcare professional students (Pharmacy and medical students) in public and private universities situated in the Southeastern region in Bangladesh.

\section{Materials and Methods}

Study design and sampling: In this crosssectional study the respondents were selected from the students of biological science (Biochemistry and Molecular Biology, Microbiology and Botany) and health care professionals (Pharmacy and medical students) in public and private universities located in the Southeastern region in Bangladesh between March 2018 to July, 2018. A simple random sampling technique was used for the selection of study participants. The total numbers of respondents were 332. All the participants willingly joined in this study providing written consent. The study protocol was approved by the ethical research committee of the Department of Pharmacy of International Islamic University Chittagong, Bangladesh.

Study questionnaire: The questionnaire was adopted from a formerly published study (Hasan et al., 2011; Jahan et al., 2021; James et al., 2014;
Tiralongo et al., 2008; Yeo et al., 2005) standardized for biological science (Biochemistry and Molecular Biology, Microbiology and Botany) and health care professionals (Pharmacy and medical students) students. The questionnaire was divided into nine sections: A: demographic information; B: General Attitudes Toward Complementary and Alternative Medicine (CAM); C: Barriers to Use of CAM Practices; D: CAM Approaches: "Alternative" or Mainstream; E: CAM resources; F: CAM Personal Use; G: CAM Approaches in Your Practice; H: first introduction with CAM approaches, I: respondent family status of CAM use; J: Knowledge about CAM therapies.

Data collection: The questionnaires were circulated among the selected students with a consent form that explained the objectives of the research and guaranteed them of their confidentiality. The respondents were given an explanation of the therapy, its most important principles and evidence base and a practical demonstration for about fifteen minutes. They were invited to complete the questionnaire immediately. The authors were present on hand to answer questions or clarify any doubt that they might have. The class leader collected all the filled-up questionnaires in each class.

\section{Results and Discussion}

This study was designed to evaluate the knowledge, attitude, and perception of university students towards the CAM health belief and practice in their daily life. Data were collected from three different fields of biological science students and two different fields of future healthcare professional students in public and private universities. The study revealed the resources of CAM information, barriers to use of CAM, CAM approaches, and knowledge about CAM therapies. Most of the students showed positive perception regarding CAM and a desire to include CAM education in their curriculum. Table 1, Figure 1 showed the demographic characteristics in which male and female were $57.2 \%$ and $42.8 \%$, respectively. Among the 332 respondents, 3.3\%, $5.1 \%, 18.1 \%, 51.2 \%$, and $22.3 \%$ were studied in first, 
second, third, fourth years and masters level study, (94.0\%) ranges between 21 to 25 years.

respectively. The age of majority of the respondents

Table 1. Biological science and medical student's demographics.

\begin{tabular}{llcc}
\hline Item & Subgroup & Number & Percentage (\%) \\
\hline Year of study & 1st year & 11 & 3.3 \\
& 2nd year & 17 & 5.1 \\
& 3rd year & 60 & 18.1 \\
& 4th year & 170 & 51.2 \\
Sex & Masters & 74 & 22.3 \\
Age group (years) & Male & 190 & 57.2 \\
& Female & 142 & 42.8 \\
& Less than 20 years & 18 & 5.4 \\
Ethnic Group & 21 to 25 Years & 312 & 94.0 \\
& More than 26 years & 2 & 0.6 \\
& Bangladeshi & 325 & 97.9 \\
Subjects & Tribal & 5 & 1.5 \\
& Non-tribal Bangladeshi & 2 & 0.6 \\
& Department of Pharmacy & 183 & 55.1 \\
& Department of Biochemistry and & 52 & 15.7 \\
& Molecular Biology & & \\
& Department of Microbiology & 17 & 5.1 \\
& Department of Botany & 11 & 3.3 \\
& MBBS & 69 & 20.8 \\
\hline
\end{tabular}

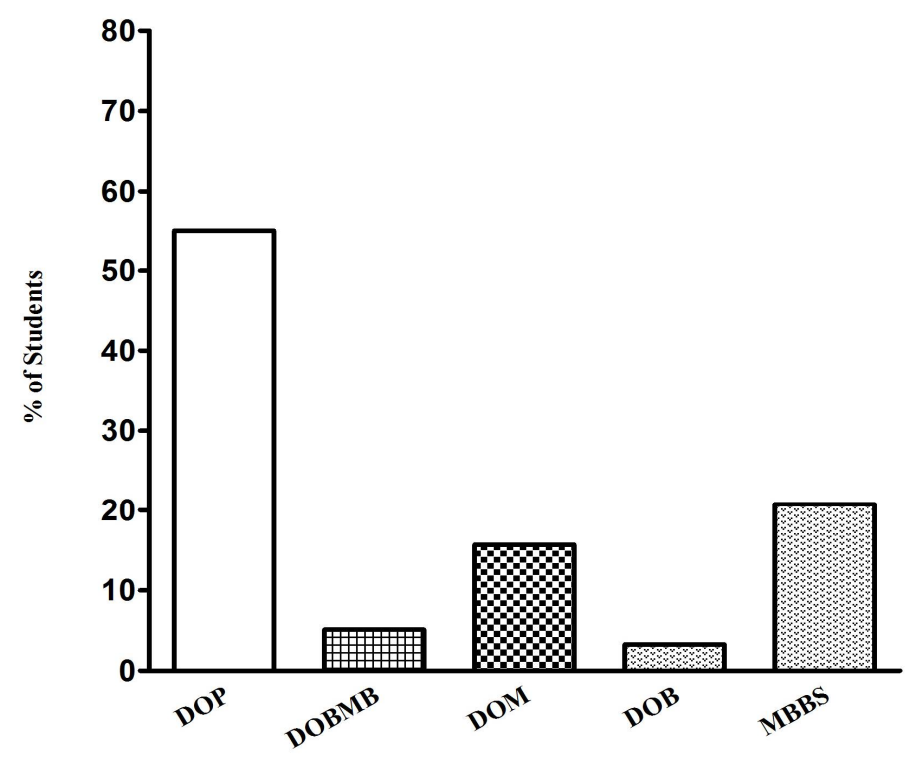

Figure 1. Investigation of CAM among biological science students and future health professional students. Where, DOP= Department of Pharmacy, DOBMB= Department of Biochemistry and Molecular Biology, DOM= Department of Microbiology, $\mathrm{DOB}=$ Department of Botany and MBBS $=$ Medical students. 
Recently, a number of studies suggest that an increasing interest in CAM has been observed among future healthcare professional students (Freymann $e t$ al., 2006; Hasan et al., 2011; Hussain et al., 2012; Tiralongo et al., 2008; Woloschuk et al., 2004). Most of the studies involved in health professional students and to later extent on biological discipline students. The respondents considered the CAM modalities such as massage (59.6\%), therapeutic/healing touch $(51.5 \%)$, bioelectromagnetic therapies $(44.9 \%)$ and herbal medicine (42.2\%) considered as clear alternative therapies whereas meditation (29.2\%), acupuncture (21.4\%), homeopathy (18.1\%), massage $(10.2 \%)$ and spiritual healing $(15.1 \%)$ as clearly mainstream therapy (Table 2).

Table 2. Pattern of CAM approaches among respondents.

\begin{tabular}{lccc}
\hline Item & $\begin{array}{c}\text { Clearly mainstream, } \\
\mathrm{n}(\%)\end{array}$ & $\begin{array}{c}\text { Neither clearly mainstream } \\
\text { nor alternative, } \mathrm{n}(\%)\end{array}$ & $\begin{array}{c}\text { Clearly alternative, } \\
\mathrm{n}(\%)\end{array}$ \\
\hline $\begin{array}{l}\text { Acupuncture } \\
\text { Bioelectromagnetic therapies, }\end{array}$ & $65(21.4)$ & $82(24.7)$ & $179(53.9)$ \\
e.g., magnets & $64(19.3)$ & $118(35.5)$ & $149(44.9)$ \\
Biofeedback & $76(22.9)$ & $115(34.6)$ & $153(46.1)$ \\
Chiropractic & $71(21.4)$ & $111(33.4)$ & $145(43.7)$ \\
Herbal medicine & $60(18.1)$ & $121(36.4)$ & $140(42.2)$ \\
Homeopathy & $91(27.4)$ & $131(39.5)$ & $141(42.5)$ \\
Hypnosis/guided imagery & $34(10.2)$ & $130(39.2)$ & $110(33.1)$ \\
Massage & $92(27.7)$ & $100(30.1)$ & $198(59.6)$ \\
Nutritional supplements & $50(15.1)$ & $130(39.2)$ & $109(32.8)$ \\
Prayer/spiritual healing & $97(29.2)$ & $131(39.5)$ & $151(45.5)$ \\
Meditation & $74(22.3)$ & $128(38.6)$ & $106(31.9)$ \\
Therapeutic/healing touch & & $87(26.2)$ & $171(51.5)$ \\
\hline
\end{tabular}

Twelve attitude statements related to CAM were included in the questionnaire to which the students could either, very strongly disagree or strongly disagree or disagree, be neutral, or very strongly agree or strongly agree or agree (Table 3 ).

Most of the students (40.7\%) believed that the integration of CAM and conventional medicine should be essential in health care setting and thought that CAM included ideas and methods from which conventional medicine could benefit (38.3\%). Among the 332 respondents, $36.7 \%$ believed that CAM practices should be included in their school's curriculum. Moreover, 39.5\% students assumed that the CAM knowledge can prompt life as a student and future professional life. Table 4 and Figure 2 showed the barriers of CAM practice among students' opinion about the constraint of CAM use in Bangladesh.

Almost $38.0 \%$ respondents considered the deficient of knowledge as the main barrier to CAM use. The quantitative data regarding barrier of CAM are ranked in following order lack of patient interest $(48.2 \%)$, lack of physician interest $(43.4 \%)$, timeconsuming (40.4\%), lack of compensation $(36.7 \%)$, lack of trained professionals $(33.7 \%)$, and lack of evidence for practices $(31.0 \%)$. The major resources of CAM information among the students were the internet $(58.7 \%)$, textbook (59.6\%), articles on clinical trials of alternative medicine therapies $(60.5 \%)$, lectures $(61.4 \%)$, hands-on experience with alternative medicine therapies $(62.7 \%)$, and using CAM therapies to promote own health $(63.3 \%)$ (Table 5). 
Moreover, $70.5 \%, 8.1 \%$, and $21.4 \%$ students know about disease pathophysiology with a remedy, brand name in specific disease cases, and at least one brand name with disease, respectively (Table 6).
Due to the increased public demand of CAM, the knowledge, attitude and perception of biological science and healthcare professional of undergraduate and graduate students have become a matter of interest.

Table 3. General attitudes toward Complementary and Alternative Medicine among respondents.

\begin{tabular}{|c|c|c|c|c|c|c|c|}
\hline Statements & $\begin{array}{l}\text { VSA, N } \\
(\%)\end{array}$ & $\begin{array}{c}\text { SA, N } \\
(\%)\end{array}$ & A, N (\%) & $\mathrm{D}, \mathrm{N}(\%)$ & $\begin{array}{l}\mathrm{SD}, \mathrm{N} \\
(\%)\end{array}$ & $\begin{array}{l}\text { VSD, } \\
\mathrm{N}(\%)\end{array}$ & $\begin{array}{l}\mathrm{X}, \mathrm{N} \\
(\%)\end{array}$ \\
\hline $\begin{array}{l}\text { Clinical care should integrate the best of } \\
\text { conventional and CAM practices. }\end{array}$ & $\begin{array}{c}61 \\
(18.4)\end{array}$ & $\begin{array}{c}69 \\
(20.8)\end{array}$ & $\begin{array}{c}135 \\
(40.7)\end{array}$ & $30(9.0)$ & $15(4.5)$ & $4(1.2)$ & $\begin{array}{c}18 \\
(5.4)\end{array}$ \\
\hline $\begin{array}{l}\text { CAM includes ideas and methods from } \\
\text { which conventional medicine could } \\
\text { benefit. }\end{array}$ & $\begin{array}{c}68 \\
(20.5)\end{array}$ & $\begin{array}{c}66 \\
(19.9)\end{array}$ & $\begin{array}{c}127 \\
(38.3)\end{array}$ & $26(7.8)$ & $12(3.6)$ & $8(2.4)$ & $\begin{array}{l}25 \\
(7.5)\end{array}$ \\
\hline $\begin{array}{l}\text { While we need to be careful in our claims, } \\
\text { a number of CAM approaches hold } \\
\text { promise for treatment of symptoms, } \\
\text { conditions, and/or diseases. }\end{array}$ & $\begin{array}{c}102 \\
(30.7)\end{array}$ & $\begin{array}{c}130 \\
(39.2)\end{array}$ & $96(28.9)$ & $2(0.6)$ & $\begin{array}{c}1 \\
(0.3)\end{array}$ & $\begin{array}{c}1 \\
(0.3)\end{array}$ & - \\
\hline $\begin{array}{l}\text { The results of CAM are in most cases due } \\
\text { to a placebo (drug without active } \\
\text { ingredients) effect. }\end{array}$ & $\begin{array}{c}128 \\
(38.6)\end{array}$ & $\begin{array}{c}175 \\
(52.7)\end{array}$ & $5(1.5)$ & $8(2.4)$ & $2(0.6)$ & $2(0.6)$ & $\begin{array}{c}12 \\
(3.6)\end{array}$ \\
\hline $\begin{array}{l}\text { CAM therapies not tested in a scientific } \\
\text { manner should be discouraged. }\end{array}$ & $\begin{array}{c}101 \\
(30.4)\end{array}$ & $\begin{array}{c}59 \\
(17.8)\end{array}$ & $68(20.5)$ & $85(25.6)$ & $16(4.8)$ & - & $3(0.9)$ \\
\hline $\begin{array}{l}\text { While a few CAM approaches may have } \\
\text { limited health benefits, they have no true } \\
\text { impact on treatment of symptoms, } \\
\text { conditions, and/or diseases. }\end{array}$ & $\begin{array}{c}97 \\
(29.2)\end{array}$ & $\begin{array}{c}126 \\
(38.0)\end{array}$ & $\begin{array}{c}109 \\
(32.8)\end{array}$ & - & - & - & - \\
\hline CAM is a threat to public health. & - & $\begin{array}{c}67 \\
(20.2)\end{array}$ & $\begin{array}{c}130 \\
(39.2)\end{array}$ & - & $\begin{array}{c}133 \\
(40.1)\end{array}$ & - & $2(0.6)$ \\
\hline $\begin{array}{l}\text { I hope to have some CAM practices } \\
\text { available to patients in my practice or } \\
\text { referral network. }\end{array}$ & $\begin{array}{c}76 \\
(22.9)\end{array}$ & $\begin{array}{c}81 \\
(24.4)\end{array}$ & $\begin{array}{c}172 \\
(51.8)\end{array}$ & - & - & - & $3(0.9)$ \\
\hline $\begin{array}{l}\text { Health professionals should be able to } \\
\text { advise their patients about commonly used } \\
\text { CAM methods. }\end{array}$ & $\begin{array}{c}63 \\
(19.0)\end{array}$ & $\begin{array}{c}69 \\
(20.8)\end{array}$ & $\begin{array}{c}133 \\
(40.1)\end{array}$ & $30(9.0)$ & $14(4.2)$ & $4(1.2)$ & $\begin{array}{c}19 \\
(5.7)\end{array}$ \\
\hline $\begin{array}{l}\text { CAM practices should be included in my } \\
\text { school's curriculum. }\end{array}$ & $\begin{array}{c}77 \\
(23.2)\end{array}$ & $\begin{array}{c}71 \\
(21.4)\end{array}$ & $\begin{array}{c}122 \\
(36.7)\end{array}$ & $24(7.2)$ & $9(2.7)$ & $7(2.1)$ & $\begin{array}{l}22 \\
(6.6)\end{array}$ \\
\hline $\begin{array}{l}\text { Knowledge about CAM is important to } \\
\text { me as a student/future practicing health } \\
\text { professional. }\end{array}$ & $\begin{array}{c}102 \\
(30.7)\end{array}$ & $\begin{array}{c}131 \\
(39.5)\end{array}$ & $94(28.3)$ & $4(1.2)$ & - & - & $1(0.3)$ \\
\hline $\begin{array}{l}\text { Most complementary therapies stimulate } \\
\text { the body's natural therapeutic powers. }\end{array}$ & $\begin{array}{c}128 \\
(38.6)\end{array}$ & $\begin{array}{c}171 \\
(51.5)\end{array}$ & $14(4.2)$ & $7(2.1)$ & $4(1.2)$ & $3(0.9)$ & $5(1.5)$ \\
\hline
\end{tabular}

Where, VSA= Very Strongly Agree, SA= Strongly Agree, A= Agree, D= Disagree, SD= Strongly Disagree, VSD= Very Strongly Disagree, $\mathrm{X}=$ Neutral 
Table 4. Barriers to CAM implementation in Bangladesh.

\begin{tabular}{|c|c|c|c|c|c|c|c|}
\hline Statements & $\begin{array}{l}\text { VSA, N } \\
(\%)\end{array}$ & $\begin{array}{c}\text { SA, N } \\
(\%)\end{array}$ & $\begin{array}{l}\mathrm{A}, \mathrm{N} \\
(\%)\end{array}$ & $\begin{array}{l}\mathrm{D}, \mathrm{N} \\
(\%)\end{array}$ & $\begin{array}{l}\mathrm{SD}, \mathrm{N} \\
(\%)\end{array}$ & $\begin{array}{l}\text { VSD, } \\
\mathrm{N}(\%)\end{array}$ & $\begin{array}{l}X, N \\
(\%)\end{array}$ \\
\hline $\begin{array}{l}\text { Lack of evidence for } \\
\text { practices }\end{array}$ & $126(38.0)$ & $46(13.9)$ & $103(31.0)$ & $47(14.2)$ & $10(3.0)$ & - & - \\
\hline $\begin{array}{l}\text { Unavailability of } \\
\text { credentialed providers }\end{array}$ & $106(31.9)$ & $\begin{array}{c}60 \\
(18.1)\end{array}$ & $\begin{array}{c}75 \\
(22.6)\end{array}$ & $\begin{array}{c}77 \\
(23.2)\end{array}$ & $\begin{array}{c}13 \\
(3.9)\end{array}$ & - & $\begin{array}{c}1 \\
(0.3)\end{array}$ \\
\hline Lack of compensation & $98(29.5)$ & $122(36.7)$ & $111(33.4)$ & $\begin{array}{c}1 \\
(0.3)\end{array}$ & - & - & - \\
\hline Too time-consuming & $\begin{array}{c}126 \\
(38.0)\end{array}$ & $\begin{array}{c}72 \\
(21.7)\end{array}$ & $\begin{array}{c}134 \\
(40.4)\end{array}$ & - & - & - & - \\
\hline Lack of physician interest & $100(30.1)$ & $64(19.3)$ & $\begin{array}{c}144 \\
(43.4)\end{array}$ & $\begin{array}{c}18 \\
(5.4)\end{array}$ & $\begin{array}{c}3 \\
(0.9)\end{array}$ & - & $\begin{array}{c}3 \\
(0.9)\end{array}$ \\
\hline Lack of patient interest & $127(38.3)$ & $\begin{array}{c}160 \\
(48.2)\end{array}$ & $\begin{array}{c}19 \\
(5.7)\end{array}$ & $\begin{array}{c}6 \\
(1.8)\end{array}$ & $\begin{array}{c}5 \\
(1.5)\end{array}$ & $\begin{array}{c}3 \\
(0.9)\end{array}$ & $\begin{array}{c}12 \\
(3.6)\end{array}$ \\
\hline Legal issues & $126(38.0)$ & $48(14.5)$ & $101(30.4)$ & $49(14.8)$ & $8(2.4)$ & - & - \\
\hline $\begin{array}{l}\text { Lack of trained } \\
\text { professionals }\end{array}$ & $112(33.7)$ & $66(19.9)$ & $63(19.0)$ & $\begin{array}{c}77 \\
(23.2)\end{array}$ & $13(3.9)$ & - & $\begin{array}{c}1(0.3 \\
)\end{array}$ \\
\hline $\begin{array}{l}\text { Lack of appropriate } \\
\text { equipment }\end{array}$ & $94(28.3)$ & $126(38.0)$ & $112(33.7)$ & - & & - & \\
\hline
\end{tabular}

Where, VSA $=$ Very Strongly Agree, $S A=$ Strongly Agree, $A=$ Agree, $D=$ Disagree, $S D=$ Strongly Disagree, VSD $=$ Very Strongly Disagree, $X=$ Neutral

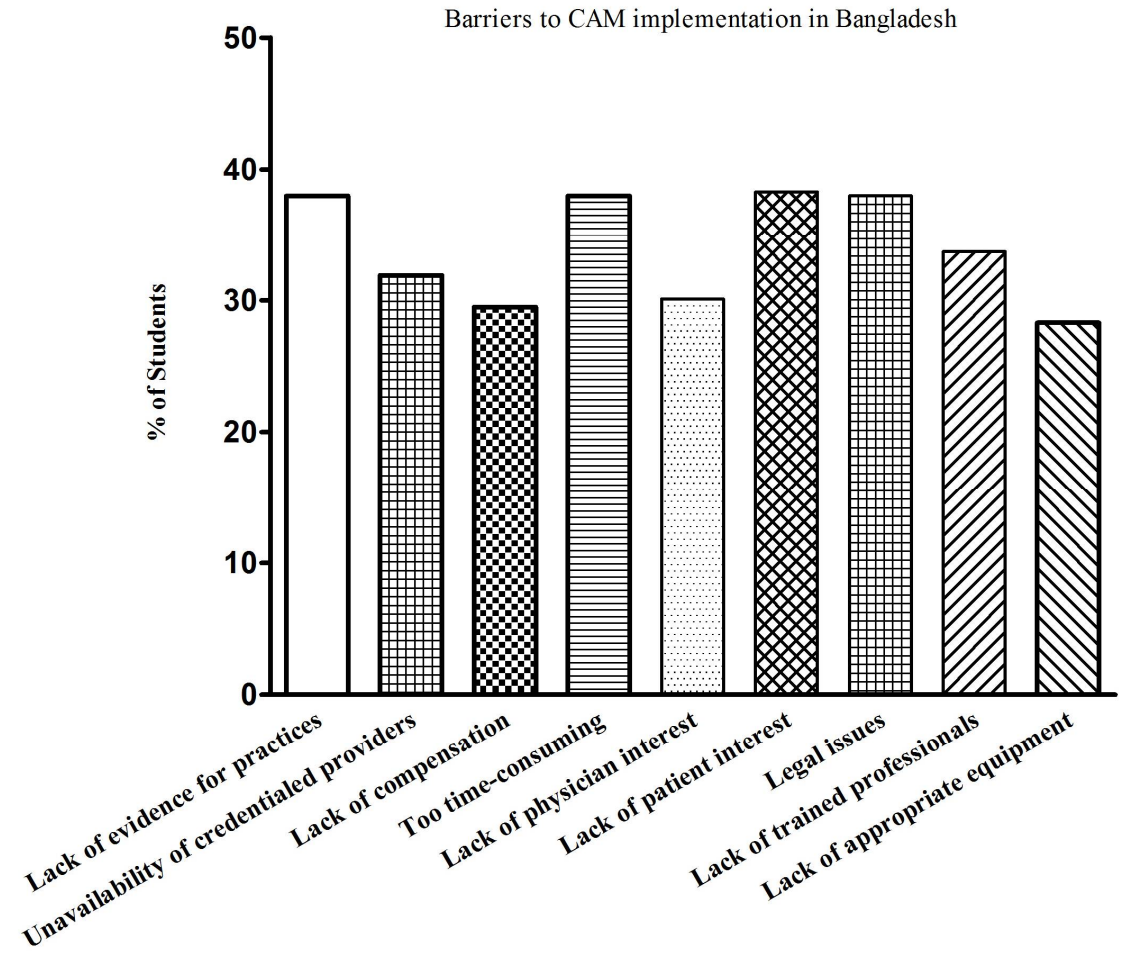

Figure 2. Perception regarding major barriers of CAM among biological science students and future health professional students. 
Table 5. Sources of CAM information among respondents $(\mathrm{N}=332)$.

\begin{tabular}{|c|c|c|c|}
\hline Statements & $\mathrm{NU}, \mathrm{N}(\%)$ & $\mathrm{U}, \mathrm{N}(\%)$ & VU, N $(\%)$ \\
\hline Internet & $5(1.5)$ & $132(39.8)$ & $195(58.7)$ \\
\hline Textbook readings & $1(0.3)$ & $133(40.1)$ & 198 (59.6) \\
\hline Articles on clinical trials of alternative medicine therapies & $2(0.6)$ & $129(38.9)$ & $201(60.5)$ \\
\hline Lectures & $3(0.9)$ & $125(37.7)$ & $204(61.4)$ \\
\hline Observation of alternative medical therapies & $1(0.3)$ & $123(37.0)$ & $208(62.7)$ \\
\hline $\begin{array}{l}\text { Hands-on experience with alternative medicine therapies } \\
\text { and patients in clinical settings }\end{array}$ & $6(1.8)$ & $130(39.2)$ & $196(59.0)$ \\
\hline Case-based learning & $3(0.9)$ & $131(39.5)$ & $198(59.6)$ \\
\hline $\begin{array}{l}\text { Using alternative medicine therapies to promote my own } \\
\text { health }\end{array}$ & $2(0.6)$ & $120(36.1)$ & $210(63.3)$ \\
\hline
\end{tabular}

Where, NU= Not useful, U= Useful, VU=Very Useful.

Table 6. Knowledge about complementary therapies among respondents $(\mathrm{N}=332)$.

\begin{tabular}{lc}
\hline Statements & N (\%) \\
\hline $\begin{array}{l}\text { Knows about disease } \\
\text { pathophysiology and remedy }\end{array}$ & $234(70.5)$ \\
$\begin{array}{l}\text { Knows about brand name in } \\
\text { specific disease cases }\end{array}$ & $27(8.1)$ \\
$\begin{array}{l}\text { Knows at least one brand name } \\
\text { with disease }\end{array}$ & $71(21.4)$ \\
\hline
\end{tabular}

The complementary and alternative form is significantly influenced by culture and tradition of the society around the world (Bodeker et al., 2007). Adequate knowledge is required to develop professional image as a CAM health care providers and conventional medicine advisors (Bodeker et al., 2007; Hasan et al., 2011). The pragmatic rate towards complementary and alternative medicine attitude and perception by the university students observed in this study is comparable with the results found earlier in Australia, Bangladesh, Pakistan and Sierra Leone (James et al., 2014; Saha et al., 2017; Tiralongo et al., 2008). In Bangladesh, local practitioner used traditional and complementary medicine against fever (1.9\%), cough and cold (7.1\%), hypertension (2.5\%), gastro-intestinal pain (3.4\%) and dysentery (1.6\%) (Bodeker et al., 2007; Harun-Or-Rashid et al., 2011). In our study, we found the main sources of CAM information were internet, surveillance of CAM therapies, textbook, articles, hands-on training and case-based learning. Previously researcher found sources of CAM information as television, newspapers articles, books and family friend who has involved in traditional and alternative medicine therapies in Ghana and Bangladesh (Ameade et al., 2016; Saha et al., 2017). A positive attitude toward CAM among biological science and healthcare professional undergraduate students was observed in this study which is similar with other studies on pharmacy and other health professional students attitudes toward CAM globally (Chaterji et al., 2007; Harris et al., 2006; Hussain et al., 2012; Kreitzer et al., 2002; Lie et al., 2006; Pokladnikova et al., 2008; Yildirim et al., 2010). Our study highlighted the barriers of CAM practice in Bangladesh were insufficient evidence of practice, unavailability of service providers, poor physician interest, poor compensation and untrained professionals. Similar challenges were also faced regarding CAM practice by physician in Lagos Nigeria, pharmacy students in Bangladesh (Awodele et al., 2012; Saha et al., 2017).

\section{Conclusion}

Biological science and healthcare professional students of Bangladesh showed positive perception on CAM uses. The CAM can be considered as safe, effective and inexpensive. As it covers wide range of diagnostic and therapeutic approaches which is encouraging for the recipients. However, deficient of 
scientific evidence, knowledge and untrained professionals were the major barriers of CAM use.

\section{Abbreviations}

$\mathrm{CAM}=$ Complementary and Alternative medicine; MBBS = Bachelor of Medicine and bachelor of Surgery

\section{Acknowledgements}

This research was supported by the Center for Research and Publication (CRP) grant (IRG 180111), International Islamic University Chittagong (IIUC), Bangladesh. Authors are also thankful to Mr. Harun Ur Rashid, Lecture, Department of Economics and Banking of IIUC to analyze data using SPSS software.

\section{References}

Ameade, E.P.K., Amalba, A., Helegbe, G.K. and Mohammed, B.S. 2016. Medical students' knowledge and attitude towards complementary and alternative medicine-A survey in Ghana. $J$ Tradit Complement Med. 6, 230-236.

Ansari, P., Uddin, M.J., Rahman, M.M., Abdullah-AlMamun, M., Islam, M.R., Ali, M.H. and Reza, A.A. 2017. Anti-inflammatory, anti-diarrheal, thrombolytic and cytotoxic activities of an ornamental medicinal plant: Persicaria orientalis. J Basic Clin Physiol Pharmacol. 28, 51-58.

Awodele, O., Agbaje, E., Abiola, O., Awodele and D., Dolapo, D. 2012. Doctors' attitudes towards the use of herbal medicine in Lagos, Nigeria. J. Herb. Med. 2, $16-22$.

Babar, Z., Jaswir, I., Tareq, A., Ali Reza, A.M., Azizi, W., Hafidz, M., Ahfter, F., Hasan, M., Farhad, S. and Uddin, M.R. 2019. In vivo anxiolytic and in vitro antiinflammatory activities of water-soluble extract (WSE) of Nigella sativa (L.) seeds. Nat. Prod. Res. 1-6.

Bellah, S.F., Islam, M.N., Karim, M.R., Rahaman, M.M., Nasrin, M.S., Rahman, M.A. and Reza, A.A. 2017. Evaluation of cytotoxic, analgesic, antidiarrheal and phytochemical properties of Hygrophila spinosa ( $\mathrm{T}$. Anders) whole plant. J Basic Clin Physiol Pharmacol. 28, 185-190.

Bodeker, G. and Burford, G. 2007. Traditional, complementary and alternative medicine: policy and public health perspectives. World Sci. Res. 5, 10-15.
Chaterji, R., Tractenberg, R.E., Amri, H., Lumpkin, M., Amorosi, S.B. and Haramati, A. 2007. A large-sample survey of first-and second-year medical student attitudes toward complementary and alternative medicine in the curriculum and in practice. Altern Complement Ther. 13, 21-30.

Freymann, H., Rennie, T., Bates, I., Nebel, S. and Heinrich, M. 2006. Knowledge and use of complementary and alternative medicine among British undergraduate pharmacy students. Pharm World Sci. 28, 13-18.

Haque, M.A., Reza, A.A., Nasrin, M.S. and Rahman, M.A. 2020. Pleurotus highking mushrooms potentiate antiproliferative and antimigratory activity against triple-negative breast cancer cells by suppressing Akt signaling. Integr. Cancer Ther. 19, 1-9.

Harris, I.M., Kingston, R.L., Rodriguez, R. and Choudary, V. 2006. Attitudes towards complementary and alternative medicine among pharmacy faculty and students. Am. J. Pharm. Educ. 70, 129.

Harun-Or-Rashid, M., Yoshida, Y., Rashid, M.A., Nahar, S. and Sakamoto, J. 2011. Perceptions of the Muslim religious leaders and their attitudes on herbal medicine in Bangladesh: a cross-sectional study. BMC Res. Notes. 4, 366.

Hasan, S.S., Yong, C.S., Babar, M.G., Naing, C.M., Hameed, A., Baig, M.R., Iqbal, S.M. and Kairuz, T. 2011. Understanding, perceptions and self-use of complementary and alternative medicine (CAM) among Malaysian pharmacy students. BMC Complement Altern Med. 11, 95.

Hossain, K.H., Rahman, M.A., Taher, M., Tangpong, J., Hajjar, D., Alelwani, W., Makki and A.A., Reza, A.A. 2020. Hot Methanol Extract of Leea Macrophylla (Roxb.) manages chemical-induced inflammation in Rodent Model. J. King Saud Univ. 32, 2892-2899.

Hossen, M.A., Reza, A.A., Ahmed, A.A., Islam, M.K., Jahan, I., Hossain, R., Khan, M.F., Maruf, M.R.A., Haque, M.A. and Rahman, M.A. 2021. Pretreatment of Blumea lacera leaves ameliorate acute ulcer and oxidative stress in ethanol-induced Long-Evan rat: A combined experimental and chemico-biological interaction. Biomed. Pharmacother. 135, 111211.

Hussain, S., Malik, F., Hameed, A., Ahmed, S., Riaz, H., Abbasi, N. and Malik, M. 2012. Pakistani pharmacy students' perception about complementary and alternative medicine. Am. J. Pharm. Educ. 76, 21.

Jahan, I., Uddin, A.B.M.N., Reza, A.A., Uddin, M.G., Hossain, M.S., Nasrin, M.S., Emran, T.B. and Rahman, M.A. 2021. Tendencies and attitudes towards dietary supplements use among undergraduate female students in Bangladesh. PLoS One. 16, e0249897. 
James, P.B. and Bah, A.J. 2014. Awareness, use, attitude and perceived need for Complementary and Alternative Medicine (CAM) education among undergraduate pharmacy students in Sierra Leone: a descriptive cross-sectional survey. BMC Complement Altern Med. 14, 438.

Kreitzer, M.J., Mitten, D., Harris, I. and Shandeling, J. 2002. Attitudes toward CAM among medical, nursing, and pharmacy faculty and students: a comparative analysis. Altern Ther Health Med. 8, 44.

Lie, D.A. and Boker, J. 2006. Comparative survey of Complementary and Alternative Medicine (CAM) attitudes, use, and information-seeking behaviour among medical students, residents \& faculty. $B M C$ Med. Educ. 6, 58.

Moni, J.N.R., Adnan, M., Tareq, A.M., Kabir, M., Reza, A., Nasrin, M., Chowdhury, K.H., Sayem, S.A.J., Rahman, M.A. and Alam, A. 2021. Therapeutic Potentials of Syzygium Fruticosum Fruit (Seed) Reflect Into An Array of Pharmacological Assays and Prospective Receptors-Mediated Pathways. Life. 11, 155.

Pokladnikova, J. and Lie, D. 2008. Comparison of attitudes, beliefs, and resource-seeking behavior for CAM among first-and third-year Czech pharmacy students. Am. J. Pharm. Educ. 72, 24.

Rahman, M.M., Reza, A.M.A., Khan, M.A., Sujon, K.M., Sharmin, R., Rashid, M., Sadik, M.G., Reza, M.A., Tsukahara, T. and Capasso, R. 2021. Unfolding the Apoptotic Mechanism of Antioxidant Enriched-Leaves of Tabebuia pallida (Lindl.) Miers in EAC Cells and Mouse Model. J. Ethnopharmacol. 278, 114297.

Saha, B.L., Seam, M.O.R., Islam, M.M., Das, A., Ahamed, S.K., Karmakar, P., Islam, M.F. and Kundu, S.K. 2017. General perception and self-practice of complementary and alternative medicine (CAM) among undergraduate pharmacy students of Bangladesh. BMC Complement Altern Med. 17, 314.
Smith, T.C., Ryan, M.A., Smith, B., Reed, R.J., Riddle, J.R., Gumbs, G.R. and Gray, G.C. 2007. Complementary and alternative medicine use among US Navy and Marine Corps personnel. BMC Complement Altern Med. 7, 16.

Tabish, S.A. 2008. Complementary and alternative healthcare: is it evidence-based? Int. J. Health Sci. 2, V.

Tiralongo, E. and Wallis, M. 2008. Attitudes and perceptions of Australian pharmacy students towards Complementary and Alternative Medicine-a pilot study. BMC Complement Altern Med. 8, 2.

Uddin, M., Ali Reza, A., Abdullah-Al-Mamun, M., Kabir, M.S., Nasrin, M., Akhter, S., Arman, M., Islam, S. and Rahman, M. 2018. Antinociceptive and Anxiolytic and Sedative Effects of Methanol Extract of Anisomeles indica: An Experimental Assessment in Mice and Computer Aided Models. Front. Pharmacol. 9, 246.

Woloschuk, W., Harasym, P.H. and Temple, W. 2004. Attitude change during medical school: a cohort study. Med. Educ. 38, 522-534.

Yeo, A.S., Yeo, J.C., Yeo, C., Lee, C.H., Lim, L.F. and Lee, T.L. 2005. Perceptions of complementary and alternative medicine amongst medical students in Singapore-a survey. Acupunct Med. 23, 19-26.

Yildirim, Y., Parlar, S., Eyigor, S., Sertoz, O.O., Eyigor, C., Fadiloglu, C. and Uyar, M. 2010. An analysis of nursing and medical students' attitudes towards and knowledge of complementary and alternative medicine (CAM). J. Clin. Nurs. 19, 1157-1166. 